\title{
E-COMMERCE WEBSITE TRANSFORMATION FOR PRIVATE TRAVEL AGENT
}

\author{
Christina Tandaju ${ }^{1 *}$, Tonny Hendratono ${ }^{1}$, Amiluhur Soeroso $^{2}$, Damiasih $^{3}$ \\ and Suhendroyono ${ }^{4}$ \\ ${ }^{1}$ Universitas Bunda Mulia, Jakarta, Indonesia \\ ${ }^{2}$ Sekolah Tinggi Pariwisata Ambarrukmo, Indonesia \\ *ctandaju@bundamulia.ac.id
}

\begin{abstract}
In the business context, the internet brings with it a transformational impact that creates a new paradigm in business, digital marketing. With the use of the internet mobile, facilitate every transaction to be done by a person like ordering food, clothing purchases, purchasing household needs, and others. Everything is facilitated by the e-commerce. For tourist, traveling is one of necessity, still however there are other requirement that is needed is social. Jakarta Hidden Tour showcases another side of Jakarta city that invites to see, feel, and experience some part of the city to discover the intercultural meeting point of view. This paper presents $E$ Commerce website transformation especially to be applied for private travel agent. It explores the transformation of the website into e-commerce at Jakarta Hidden Tour, studies the system from e-commerce Jakarta Hidden Tour and formulates future development for ease of transaction. The results show that the Jakarta Hidden Tour starts from using platforms WordPress to BlogSpot because it is free and easy to use. The e-commerce system is then changed to online data. Future development plans can adapt to an increasingly advanced era of application creation, online booking, online transaction or payment as well as development of a tour destination.
\end{abstract}

Keywords - Transformation; E-Commerce; Website; Travel agent

\section{INTRODUCTION}

In 1973 - 1990, the term interconnected networking was introduced in a paper on TCP / IP [1-3]. Literally, the interconnected networking is defined as a series of connected computers in several sequences. The series of centers that formed the Internet began in 1969 as the ARPANET built by the ARPA (United States Department of Defense Advanced Research Projects Agency). Some initial investigations contributed by the ARPANET including a decentralized network, queuing theory, and packet switching [4-6]. In 1981, the National Science Foundation developed a backbone called CSNET with a capacity of $56 \mathrm{Kbps}$ for every institution in government. On January 1, 1983, the ARPANET traded its central circuit protocol, from NCP to TCP / IP. This is the beginning of the Internet that we know today. Then in 1986, IETF developed a server that serves as a coordination tool between DARPA, ARPANET, DDN, and Internet Gateway. In the 1990s, the Internet has grown and connects many users of existing computer networks.

In 1991 to present, business systems in the IT field first occurred when CERN collected payments from its members to tackle its operational costs. In 1992, Internet community began to form and the introduction of the term World Wide Web (www) by CERN [7]. In

Received: April 15, 2019

Reviewed: June 18, 2019

Accepted: June 28, 2019

" Corresponding Author

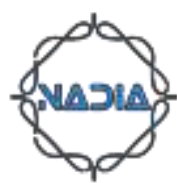


1993, the NSF established InterNIC to provide Internet services related to directory and data storage and database (by AT \& T), registration services (by Network Solution Inc.), and information services (by General Atomics / CERF.net). In 1994, the growth of the internet driven very fast and began to penetrate into various aspects of human life and became an inseparable part of human beings. In 1995, public companies began to be allowed to become providers by buying networks in the backbone. This step begins the development of information technology, particularly the Internet and researches to develop more sophisticated systems and tools [8]. In general, IT talks about the management of computer-based technologies that include the management or hardware management, software, and information systems in the desired context $[9,10,11]$.

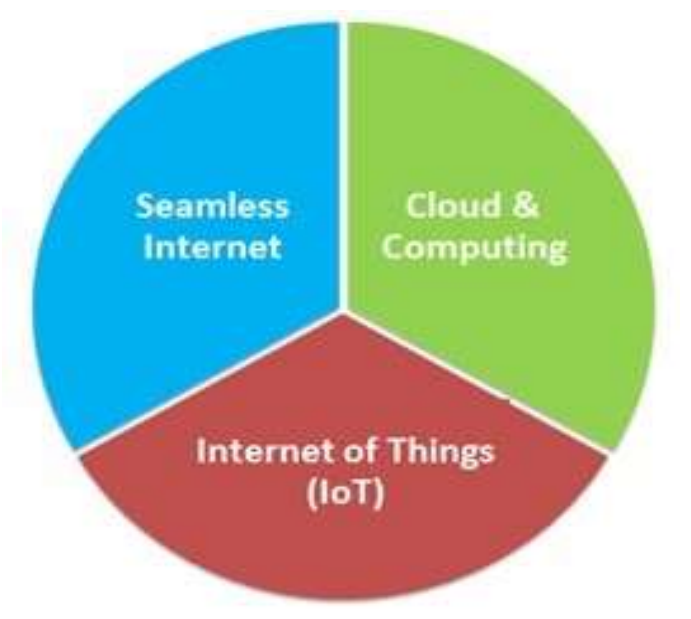

Fig. 1 Information Technology and Digital Era

The development of IT to date, a group of people can be called a digital society which is characterized by the high usage of some technologies (See Figure 1) which further signifies the growth of the digital age, including:

a. Seamless Internet

Internet access is no longer static (stationary), but mobile, where internet users can move freely in activities, for example in conducting business meetings that pass the limits of space and time (virtual meeting), to access information anywhere and anytime [12].

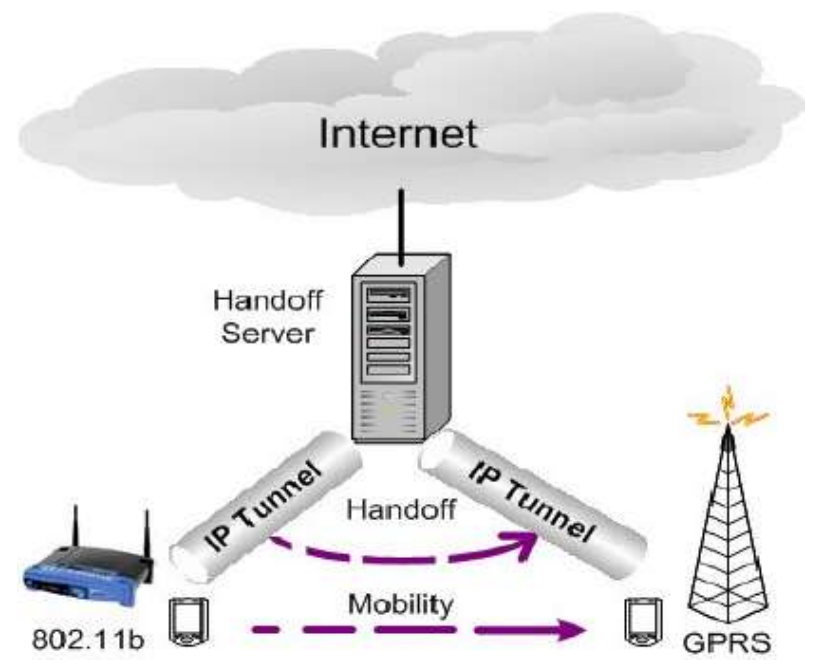

Fig. 2 Universal Seamless Handoff Architecture [12] 


\section{b. Cloud \& Computing}

Storage and data compilation in Cloud, where users no longer need to think about things like maintenance, storage, and data security because they have been prepared as an add-on service by the provider. The most common example now is the emergence of virtual stores that paradoxically begin to beat physical stores [13].

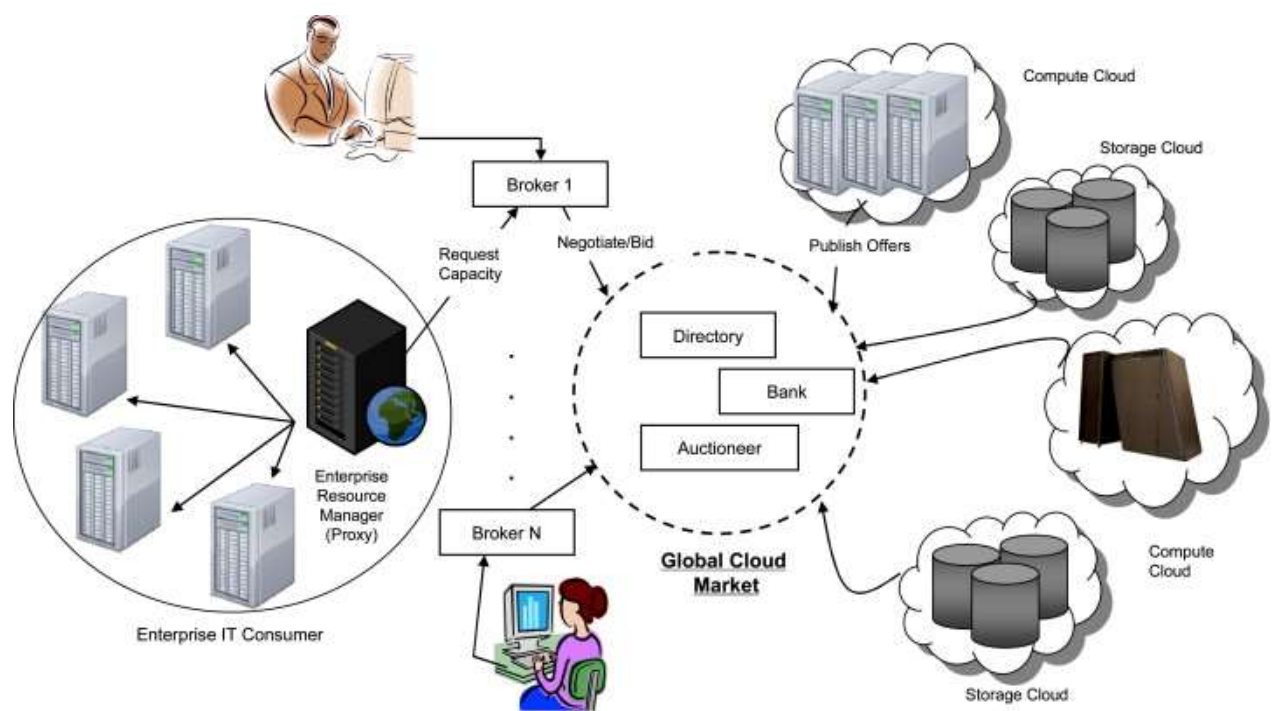

Fig. 3 Cloud computing [13]

c. Internet of Things (IoT)

The condition of connecting any real thing (product) in the real world through a network globally and performing a specific function [14].

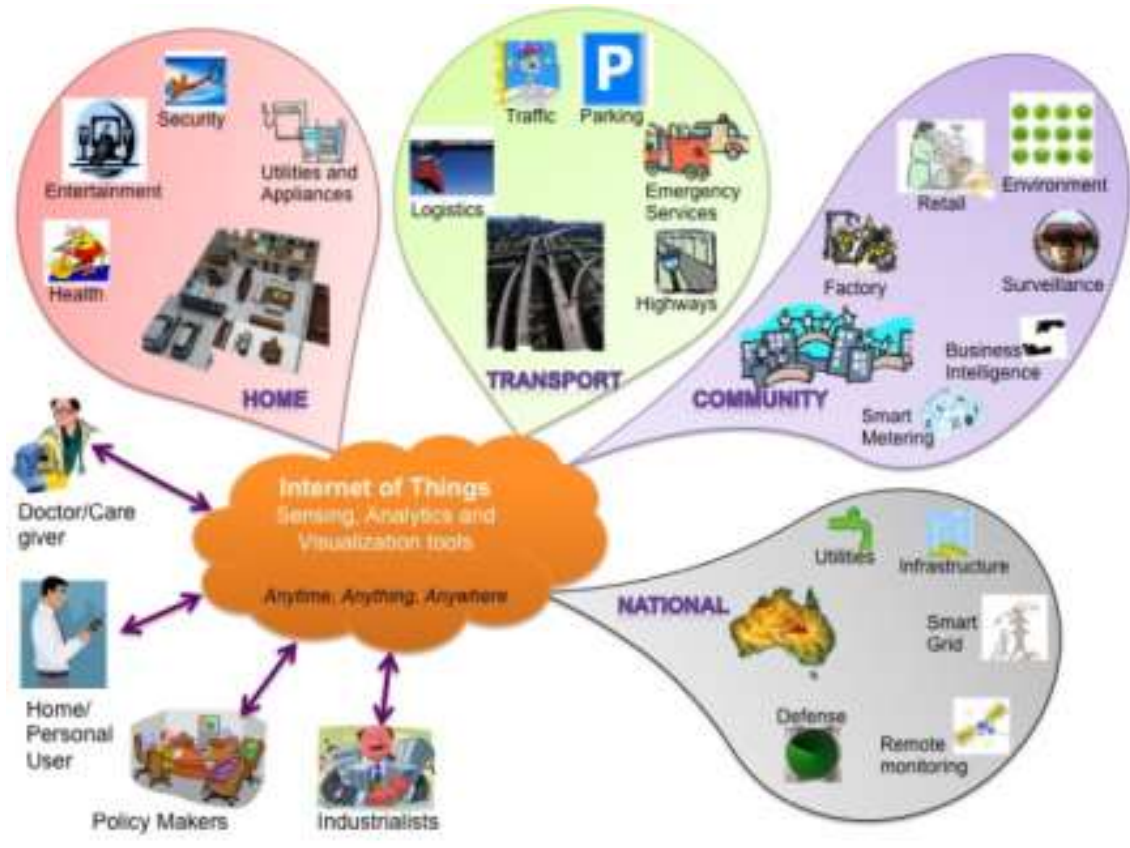

Fig. 4 Internet of Things [14]

How does it feel to have an experience when the refrigerator in our kitchen has been able to order our favorite drinks that have been running out? From some of the above, it 
cannot be denied that the digital era has become a part of daily life of society in general. Changes that occur in the area of information technology indirectly force the community to continue to connect, to finally bring the generation connected. The rapid development of information technology to make internet users in Asia growing rapidly up to 1319 percent during the period of 2000-2015. According to Internet Worlds Stats data, internet users in Asia currently reach 1.62 billion people with 40.2 percent penetration of the total population of 4 billion people (See Figure 5).

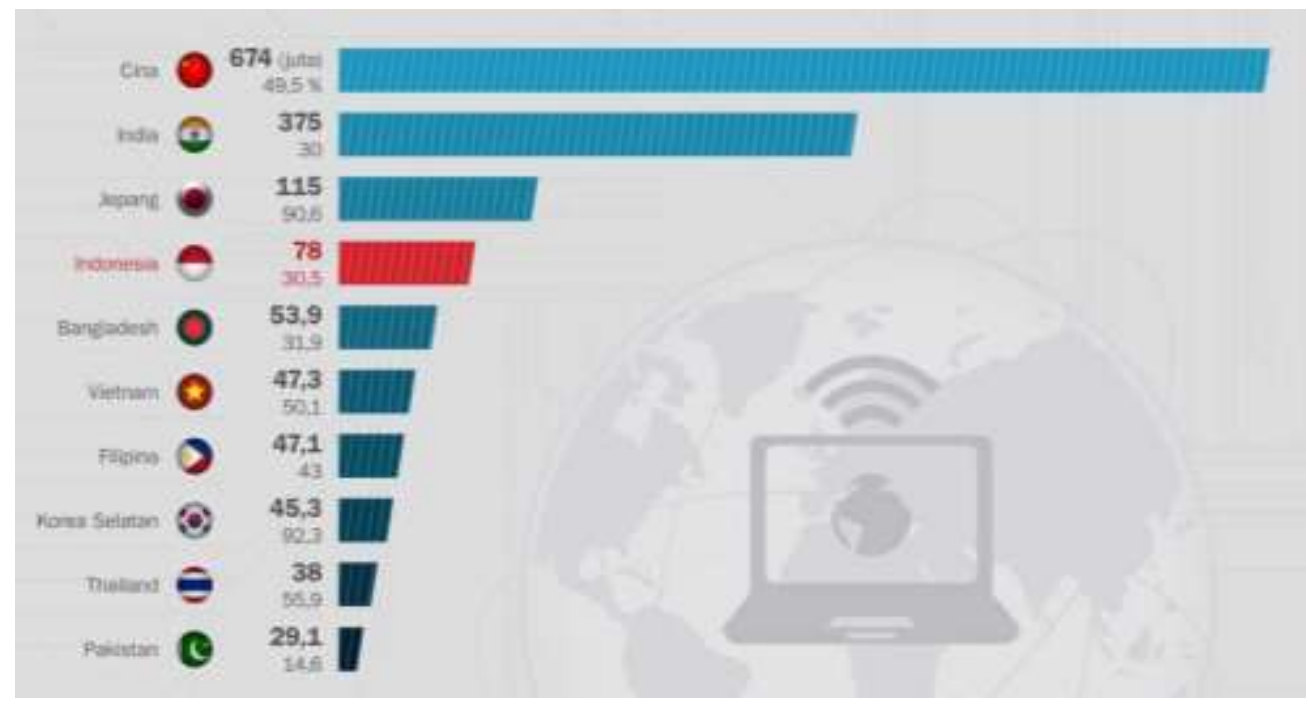

Fig. 5 Internet users in Asia

From Figure 5, a total of 674 million Asian internet users come from China [15]. In line with the development of the internet, there is a new understanding of marketing paradigm in the form of market-oriented or consumer-oriented marketing concept or marketing revolution in the form of electronic marketplace $[16,17,18,19]$. In the business context, the internet brings with it a transformational impact that creates a new paradigm in business, digital marketing [20]. If it was known to be a traditional face-to-face business interaction model, the interaction model has now evolved toward a modern, electronic-based or faceless e-commerce interaction, Business to Business (B2B), Business to Customer (B2C), and Customer to Customer (C2C) with the final target serving segment of one [16]. The Internet has some appeal and excellence for both consumers and organizations. The Internet is also the latest electronic media that supports e-commerce (electronic commerce) and experienced rapid growth. Simplistically by creating a homepage and serving product orders via the internet, it can be said as a global marketer running e-commerce

With the use of the mobile internet, facilitate every transaction to be done by a person like ordering food, clothing purchases, purchasing household needs, and others [21]. Everything is facilitated by the e-commerce. Another convenience is traveling required for refreshing. For tourists, traveling is one of necessity, but there are other requirement that is needed is social. Jakarta Hidden Tour showcases another side of Jakarta city that invites to see, feel, and experience some part of the city to discover the intercultural meeting point of view [22]. Based on the above explanation, therefore there is a need in further study about E-commerce website transformation for private travel agent.

The research questions are raised as: (1) "How to transform the website into ecommerce at Jakarta Hidden Tour; (2) What is the system from e-commerce Jakarta Hidden Tour; and (3) What is the future development for ease of transaction?". Therefore the objectives of this work are as following:

a. We transformation of the website into e-commerce at Jakarta Hidden Tour, 
b. We develop the system from e-commerce Jakarta Hidden Tour and

c. We formulate future development for ease of transaction.

The benefits of this research will increase knowledge in the context of marketing channels, issues and transformations / new trends of marketing channel in hospitality and tourism. The rationale of this research is to see how the process of website transformation that initially provide information developed into e-commerce to facilitate transactions in Jakarta Hidden Tour.

\section{INTERNET: THE NEW PARADIGM OF INTERNATIONAL MARKETING}

The new paradigm in international marketing is beginning to influence the marketing concept. This is in line with the opinion that the company in designing and direct activities in choosing a target market is based on the needs and desires of the customer [19]. However, the internet provides a different environment and approach to international marketing. A new paradigm of international marketing is likely to be developed to explain the shift of national marketing towards electronics. According to Hoffman and Novak [23], the new marketing paradigm is characterized as a turn of activity from the conventional One-to-Many communication model to the Many-to-Many communication model. In the One-to-Many model, a single company seeks to capture the attention of many consumers through traditional and non-interactive mass media such as TV and newspapers. In the Many-to-Many model, information is not easily sent from the sender to the recipient but mediated by an environment formed from participation and expectations. Therefore, consumers can interact with communication media and contribute to commercial content [19]. The current business competition in the consumer value creation business consists of 2 (two) kinds of world marketing strategies, namely the physical market (marketplace) and virtual / marketplaces (marketspace). Eid and Trueman [19] also stated that the internet overthrew the role of strategy and the old competition with a new role of syndicate concept, which is a business work by extending the structure to E-Business. Companies entering the syndicate network will think back about their products, relationships, and core capabilities.

Using the Internet improves operational effectiveness that does not provide a competitive advantage. Competitive advantage on the internet tends to be short because competitors are easy to monitor. When companies see that competitors have service or provide better, then they will also do the same [24]. Eid and Trueman [19] illustrate the concern for replacing supply and demand. The same thing was also expressed that the internet has the power to change customers so that an explanation of the paradigm shift that they call customer-to-business marketing is needed [19]. Brynjolfsson and Smith in [25] stated that through the Internet will be closer to perfect market because the information spontaneous and buyers can compare products / services available with other sellers around the world. The Diffusion of Innovation Theory basically explains as the process by which an innovation is communicated through certain channels over time among the members of a social system. It is further explained that the diffusion is the spread of a new idea from its source of invention or creation to its ultimate users or adopters. The process of innovation diffusion comprises 4 (four) main elements as follow:

a. Innovation That is an idea, action, or item that is considered new by someone

In this case, the novelty of innovation is measured subjectively according to the view of the individual who receives it. If an idea is considered new by someone then it is an innovation for that person. The 'new' concept in an innovative idea does not have to be new at all.

b. Communication channels 
The purpose of communication is the achievement of a mutual understanding between two or more participants communication of a message (in this case is a new idea) through a particular communication channel.

\section{c. Duration}

Time is an important element in the diffusion process. Dimensions time, in the diffusion process, is influential in terms of:

- The process of innovation decision making,

- One's innovative: relatively earlier or slower in accepting innovation,

- The speed of adoption of innovation in social systems (how many members of a system adopt an innovation over a period of time).

d. Socio-cultural system

Discussion of innovation occurs within a socio-cultural system. In a socio-cultural system there is a social-cultural structure, individual or group of individuals, and certain norms. Travel Cycle that describes the stages that continue to flow in the process of tourism. The first stage is dreaming, someone gets inspiration to come to a particular tourist attraction. The next stage of researching to find more detailed information about the desired tourist destination. This information search is done to convince tourists before booking. The next stage is experiencing, when tourists enjoy travel tours that have the opportunity to gain new experiences that may not exist in the reviews obtained. After a tour it is a sharing stage when travelers share their holiday experiences, and it is a trend that the experience of one person being shared will be an inspiration to others.

\section{RELATED WORKS}

Research on Adoption of E-tourism in the Hotel Industry in Padang City: Cluster Identification Based on Website Features Characteristic by Vera, et al. in [26] aims to know the website adoption rate. This is the basic concept of research to explain contextual, organizational, managerial, and e-commerce (COME) factors in the hospitality industry. Using qualitative studies in West Sumatra, the theory of innovation diffusion as a supporter of analysis and using the concept of e-commerce implementation in asking questions. The conclusion of the research is that E-tourism provides an opportunity to increase that capacity in the hospitality industry. Hotel $\mathrm{S}$ is still at the cluster level 0 , which means the company cannot be classified as an e-tourism user. Because the company is still limited to utilizing the use of email and Facebook only. And until now there is no intention company to build and manage a website for the company, because the website is not too needed company. At the Hotel P Company, the company uses e-tourism with one of the reasons to maintain a corporate prestige, and not yet take advantage of e-tourism content services for its customers. The company is still in cluster level 2, where the company's e-tourism has been managed by a special section, and contains information on company information and information about products and services. While at the cluster level 3 is Hotels Q and R, because the company has increased the use of e-tourism in their company, by communicating online with consumers and suppliers. Through this research can also be seen matters relating to the factors that affect the use of the website, and the factors why etourism developed in a company. The equation of this research is to discuss about the use of e-commerce in travel companies. The difference is this study discusses the system, the reason for the transformation, as well as the future development for ease of transaction.

The second study on Internet Marketing: New Concepts and Problems of the World of Marketing by Sutejo [27]. This article alludes to the effect of internet marketing on marketing mix and the foundation of developing a new paradigm of marketing. The conclusion is first, the use of the internet changed some elements of the traditional marketing mix approach. The key to successful marketing strategies over the internet is an interactive strategy. Secondly, the internet provides a different environment and approach 
to international marketing. The Internet makes the fundamental turn of mass marketing into personalized marketing. Marketing mix for 5P internet marketing, i.e. product, price, personalization, promotion, and place. Internet marketing allows the transformation of traditional trading activities from non-electronic to electronic plat form. Therefore, there is a new paradigm of marketing to explain international marketing in the electronic age. The new marketing paradigm is built on 7 (seven) dimensions that distinguish traditional marketing and internet marketing, i.e. time perspective, dominating marketing function, communication mode, value creation, competition base, market nature, and economic thinking. The equation with this research is about internet marketing. The difference is that the study of the world of marketing while research researchers about the world of marketing in travel for ease of transactions viewed from the system.

Third research on the Design of Web-Based E-Tourism System as a medium of Tourism Marketing of Jepara City by Adriani Terina. This research concerning electronic tourism, e-tourism helps the tourism business process as well as taking advantage of the internet to interact with all stakeholders in the tourism sector. Tourism marketing methods are the best way to get tourism information is very high. E-tourism as a new breakthrough in the promotion, marketing and sales of tourism is expected to be a significant increase in the tourism sector in the Jepara city. The similarity is about e-commerce and tourism. The difference is in the tourism of Jepara city, discussion of research on transformation into ecommerce from the marketing side.

The fourth research on E-Commerce Website Application Database Based Design for Tour \& Travel by Hakiki Fauzi. This study discusses the database as a research object to implement e-commerce applications such as website for tour \& travel. With this application, will facilitate services and access to information and management of haj and Umrah data. Such as facilitate the provider of tour \& travel services to dispatch pilgrims who want to perform the pilgrimage and Umrah. So that will get efficiency of work of tour \& travel service provider in management of haj and Umrah data, presentation of information more easily and interactive, and give better service to consumer. With an interactive presentation of Hajj and Umrah information, surely it can enhance the brand and prestige of tour and travel.

\section{MATERIAL \& METHODOLOGY}

This work is a case study-based research. The research method used is qualitative method by using constructivist paradigm with diffusion theory of technological innovation and travel cycle concept. The object of research is the website / BlogSpot Jakarta Hidden Tour. Jakarta Hidden Tour is Jakarta Private Travel which invites tourists to get around to the slums to see the other side of Jakarta and the original side of Jakarta Indonesia. Tourists who follow this tour are foreign tourists from abroad. Primary data collection techniques obtained from interviews with Mr. Ronny as the owner and tour guide of Jakarta Hidden Tour and Foreign Tourists who have participated in this tour and observations while secondary data obtained from the website / BlogSpot, videos publications and publicity, previous research similar to previous research reference that support the information needed to complete this research. The technique of data analysis is from the data that has been collected then in the analysis with the theory of diffusion of innovation and analysis of the existing case studies of future developments with all the possibilities that exist.

\section{RESULTS AND DISCUSSION}

Jakarta Hidden Tour (JHT) is currently still using BlogSpot. Originally was jakartahiddentour.wordpress.com and now has changed to realjakarta.blogspot.com. Jakarta Hidden Tour is a tour made by Ronny Poluan with the aim to help the lives of underprivileged people, approach methods by winning the hearts of the children of the 
villagers, then provide 3E of Emergency, Education, Empowerment activities for villagers, especially children, the villagers believed in Ronny Poluan and allowed a tour of the residents' houses in turn. This tour is really specific and private, and 50\% surpluses of the fee-donation. This tour invites tourists to have a social soul to share and give. Tourists can give keepsakes to the people and children in the village can be pencils, books, clothes, toys, soaps, and others. Tourists see Jakarta Hidden Tour is a unique tour and they need because of Western culture to live individually so get the spotlight from various media as well as from TripAdvisor which is a website that provides reference tourist spots. JHT is one of the tour that must be followed by tourists if playing in Jakarta. The JHT thinks differently, first, JHT thinks about the interaction between visitors and residents. Second, JHT concern about humanity, cultural, and environmental. Third, the aim of this tour is to hold a meeting socio-cultural, and through discussions with, develop a shared awareness of: humanity, culture, and environmental. With this tour, Jakarta - Indonesia. The JHT initiative is to make a unique, lovely and specific tour of Jakarta. With this tour, tourist will invite to the municipalities and malls to meet the ordinary people, mingle with villagers, and after that they will discuss about them daily lives. They tour the goal, how to help the poor people, they friends that they met who become they family.

The uniqueness, specifics, and experience gained by tourists, make tourists give positive comments, and give recommendations to other foreign tourists to follow this tour. In addition, their experience is also poured through BlogSpot so that JHT increasingly known by foreign tourists. JHT is also a spotlight for Indonesian media such as Pravda Photography, The Jakarta Post, TransTV Reportage, The Jakarta Globe, France 24 Int'1 News, AFP - Agence France Press, Jakarta Newspaper, TVOne what's Indonesia, CNN, TV3 Catalonia - Spain, VOA, Kompas, MetroTV. There are 5 tour locations namely Minima Tour that is using Mikrolet to Lorong Village, and then by bajaj or ojek direct to Pikal Village; Social Humanity Tour that is around the Old City, then see The Great River, Kota Diamond Drawbridge, and walk to the fish market, then take a Pedi cab to The Village; Ciliwung Tour is going around and meet with people in the village of Kali Ciliwung by bamboo boat ride; Kampong Tour and Maxima Tour will come soon. Previously there was the Kampung Luar Batang which became a tourist destination for JHT but after evicted, finally tour Kampung Luar Batang abandoned. Mr. Ronny Poluan as tour guide as well as owner of JHT as resource persons interviewed about the website system of JHT. Due to limited funds and limited ability of technology, Mr. Ronny just make WordPress first because it is free and easy in the making. Initially only a few tourists know, but because of the unique, tourists share stories through their blogs and they also provide positive feedback to my blog. For transactions, reservation tour at JHT is very easy just by booking by email already listed, and cash payment when meeting with Mr. Ronny or when meeting at the meeting point. Schedule and tour options already exist, just choose and booking the schedule, after booking by email, the name will be listed on BlogSpot JHT according to the schedule and destinations selected.

From the concept of Travel Cycle that describes the stages that continue to flow in the process of tourism. The first stage is dreaming, someone gets inspiration to come to a particular tourist attraction. At this stage, foreign tourists are inspired to visit the Indonesian capital Jakarta by searching for information from reviews in tourism web, blogs, travel videos, etc. The next stage of researching to find more detailed information about the desired tourist destination. This information search is done to convince tourists before booking. In this search stage, travelers search and see the itinerary of JHT BlogSpot. After determining the tourist attraction to be visited eat tourists will make the booking stage to obtain certainty for potential tourists to travel the desired tour. Booking stage is done when the tourists are interested and choose the option according to the selected schedule then make a booking via email to jaktour@gmail.com. The next stage is experiencing, when tourists enjoy travel tours that have the opportunity to gain new experiences that may not exist in the reviews obtained. At this stage, tourists come to the 
village, follow JHT in accordance with selected tour and feel the uniqueness and difference and new experience when the tour is socialization with friendly citizens. After a tour it is a sharing stage when travelers share their holiday experiences, and it is a trend that the experience of one person being shared will be an inspiration to others. At this stage we can find experience stories through JHT tourist blogs and JHT feedback.

E-commerce or electronic commerce is also an activity related to the purchase, sale of goods or services marketing with the utilization of electronic systems or internet e.g. computer network. E-commerce also involves activities related to the process of electronic transactions such as electronic funds transfer, electronic data exchange, inventory data processing systems performed with computer systems or computer networks and so forth. Based on the results of interviews with Mr. Ronny, currently only marketing done through BlogSpot and Facebook supported by TripAdvisor. For booking process, exchange data via email and post the name and schedule in BlogSpot after the booking process. This can be called e-commerce. The type of e-commerce used is B2C. B2C because of the type of business that is done between business people and consumers, such as between manufacturers who sell and offer their products to general consumers online. Here, Mr. Ronny as a businessman sells and offers tour private products online, without expecting any feedback from tourists who have followed JHT. In addition, JHT also has not cooperated with travel companies and their product not marketed by other travel.

Simon as one of the participants from JHT said he would recommend JHT to his friends because with JHT, Simon can feel friendly from Jakarta people, real Jakarta not fake like malls, and learn a lot about Jakarta history. In addition, Simon gets JHT information from TripAdvisor. Simon advises the Indonesian government to improve the physical issues related to history and culture such as the museums are very poor quality, no restoration of the old town, it is actually difficult to learn about Indonesia's history. Theory of Innovation Diffusion by Rogers (1961), basically explains as the process by which an innovation is communicated through certain channels over time among the members of a social system. "From a website containing only the information needed by the audience to transform because of the existence changes that facilitate the community such as ease of finding information, transacting, data exchange, and ease of use. In this study, initially only contains information and data exchange, in the future and can be developed with virtual money that allows customers to conduct tour transactions wherever and whenever. To its depth, JHT will follow the existing trend if there are sponsors who want to support and cooperate to create website with complete transaction convenience facility such as online booking, online payment can use credit card, donation fee online, and application from real Jakarta. In addition, it may be possible to develop a private tour business for the introduction of Jakarta's original Betawi culture. Furthermore, it can also to organize a tour to Kampung Betawi, therefore tourists will have experience to play Ondel-ondel i.e. a traditional musical instrument Betawi, learn and watch Betawi traditional dance. In addition, JHT can also open up new jobs for the community visited by selling handmade pieces as souvenirs or souvenirs.

\section{CONCLUSION AND RECOMMENDATION}

This paper has presented E-Commerce website transformation especially to be applied for private travel agent. It can be concluded that the Jakarta Hidden Tour has moved from WordPress to BlogSpot since it is free and easy to use. The e-commerce system from Jakarta Hidden Tour is started from the booking process and confirmation about the desired schedule as stated in BlogSpot. Future development plans can adapt to an increasingly advanced era of application creation, online booking, online transaction or payment as well as development of a tour destination to Kampung Betawi. For further research, it is suggested to continue this research with the object of wider study, and can provide reference for future marketing, hospitality and tourism research, for travel 
companies. This research can give input and also good strategy for Marketing especially at the level of ease of transaction.

\section{REFERENCES}

[1] Cerf, V. and Kahn, R., 1974. A protocol for packet network intercommunication. IEEE Transactions on communications, 22(5), 637-648.

[2] Fall, K.R. and Stevens, W.R., 2011. TCP/IP illustrated, volume 1: The protocols. Addison-Wesley.

[3] Dunkels, A., Alonso, J., Voigt, T., Ritter, H. and Schiller, J., 2004, February. Connecting wireless sensornets with TCP/IP networks. In International Conference on Wired/Wireless Internet Communications, 143-152. Springer, Berlin, Heidelberg.

[4] McQuillan, J., Richer, I. and Rosen, E., 1980. The new routing algorithm for the ARPANET. IEEE transactions on communications, 28(5), 711-719.

[5] Salus, P.H. and Vinton, G., 1995. Casting the Net: From ARPANET to Internet and Beyond... AddisonWesley Longman Publishing Co., Inc.

[6] Abbate, J.E., 1994. From ARPANET to Internet: A history of ARPA-sponsored computer networks, 1966--1988.

[7] Berners-Lee, T., Cailliau, R., Groff, J.F. and Pollermann, B., 2010. World-wide web: The information universe. Internet Research, 20(4), 461-471.

[8] Buhalis, D. and Law, R., 2008. Progress in information technology and tourism management: 20 years on and 10 years after the Internet-The state of eTourism research. Tourism management, 29(4), 609-623.

[9] Cooper, R.B. and Zmud, R.W., 1990. Information technology implementation research: a technological diffusion approach. Management science, 36(2), 123-139.

[10] Rockart, J.F. and Short, J.E., 1989. IT in the 1990s: Managing organizational interdependence. MIT Sloan Management Review, 30(2), p.7.

[11] Taylor, S. and Todd, P.A., 1995. Understanding information technology usage: A test of competing models. Information systems research, 6(2), 144-176.

[12] Chen, L. J., Sun, T., Chen, B., Rajendran, V., \& Gerla, M. (2004, May). A smart decision model for vertical handoff. In ANWIRE international workshop.

[13] Buyya, R., Yeo, C.S., Venugopal, S., Broberg, J. and Brandic, I., 2009. Cloud computing and emerging IT platforms: Vision, hype, and reality for delivering computing as the 5th utility. Future Generation computer systems, 25(6), 599-616.

[14] Gubbi, J., Buyya, R., Marusic, S. and Palaniswami, M., 2013. Internet of Things (IoT): A vision, architectural elements, and future directions. Future generation computer systems, 29(7), 1645-1660.

[15] Harwit, E. and Clark, D., 2001. Shaping the internet in China. Evolution of political control over network infrastructure and content. Asian Survey, 41(3), 377-408.

[16] Arnott, David C. dan Susan Bridgewater, 2002. "Internet, Interaction and Implications for Marketing," Marketing Intelligence and Planning, 20 (2):86.

[17] Bakos, Yannis dan Brynjolfsson, Erik, 1999. "Bundling information goods: Pricing, profits, and efficiency," Management Science, 45 (12):1613.

[18] Chaffey, D., Mayer R., Johnston, K., dan Elliss-Chadwick, F., 2000. Internet Marketing: Strategy, Implementation, and Practice. England: Prentice Hall.

[19] Eid, Riyad dan Myfanwy Trueman, 2002. "The Internet: New International Marketing Issues," Management Research News, 25 (12):54.

[20] Teece, D.J., 2010. Business models, business strategy and innovation. Long range planning, 43(2-3), 172194.

[21] Okazaki, S. and Hirose, M., 2009. Does gender affect media choice in travel information search? On the use of mobile Internet. Tourism Management, 30(6), 794-804.

[22] Prasetyanti, R., 2015. Slum Kampong Tourism "Jakarta Hidden Tour": Designing Eco-Cultural Based Pro-Poor Tourism. European Journal of Interdisciplinary Studies, 3(1), 111-121.

[23] Hoffman, D.L. and Novak, T.P., 1996. Marketing in hypermedia computer-mediated environments: Conceptual foundations. The Journal of Marketing, 50-68.

[24] Chaffey, D., 2000. Achieving Internet marketing success. The Marketing Review, 1(1), 35-59.

[25] Brynjolfsson, E. and Smith, M.D., 2000. Frictionless commerce? A comparison of Internet and conventional retailers. Management science, 46(4), 563-585.

[26] Vera, P.M., and Iboo, A.V. 2016. Adopsi E-tourism pada Industri Perhotelan Kota Padang: Identifikasi Klaster Berdasarkan Karakteristik Fitur Website. Jurnal TEKNOSI, 02(03).

[27] Sutejo, B.S., 2010. Internet Marketing: Konsep dan Persoalan Baru Dunia Pemasaran. Jurnal Manajemen Maranatha, 6(1), 41-56.

[28] Andria Terina, N., 2013. Perancangan Sistem E-Tourism Berbasis Web sebagai Media Pemasaran Pariwisata Kota Jepara (Doctoral dissertation, Program Studi Teknik Informatika FTI-UKSW).

[29] Hakiki Fauzi, M., 2017. "Perancangan Database Aplikasi E-Commerce Berbasis Website untuk Tour \& Travel” (Doctoral dissertation, UIN Sunan Gunung Djati Bandung). 